Acta Zoológica Mexicana (nueva serie), Volume 37, 1-11.

\title{
First record of Neurosystasis Satchell in Mexico, with the description of one new species (Diptera, Psychodidae), and the validation of Chuspilepia Omad, Mangudo \& Gleiser as subgenus
}

\section{Primer registro de Neurosystasis Satchell en México, con la descripción de una nueva especie (Diptera: Psychodidae) y la validación de Chuspilepia Omad, Mangudo \& Gleiser como subgénero}

\section{1JUANA DURÁN-LUZ, (D) 1*SERGIO IBÁÑNEZ-BERNAL, ²GUILlermo HUGO OMAD}

${ }^{1}$ Red Ambiente y Sustentabilidad, Instituto de Ecología A.C., Carretera Antigua a Coatepec No. 351, Colonia El Haya, C.P. 91073, Xalapa, Veracruz, México.

2Universidad Nacional de la Patagonia San Juan Bosco, Sede Esquel. Km 16.4, Esquel, Argentina.

OPEN ACCESS

Responsible editor: Karina D. Rivera-García

*Corresponding author:

(iD) Sergio lbáñez-Bernal sergio.ibanez@inecol.mx

Cite:

Durán-Luz, J., Ibáñez-Bernal, S., Omad, G. H. (2021) First record of Neurosystasis Satchell in Mexico, with the description of one new species (Diptera, Psychodidae), and

the validation of Chuspilepia

Omad, Mangudo \& Gleiser as subgenus. Acta Zoológica Mexicana (nueva serie), 37, 1-11. 10.21829/azm.2021.3712361 elocation-id: e3712361

Received: 15 October 2020 Accepted: 11 October 2021 Published: 18 October 2021
ABSTRACT. Neurosystasis Satchell is newly recorded in Mexico by means of the description of a new species. Specimens captured in a tropical deciduous forest in southern Puebla, central Mexico, were examined and determined as a species new to science. The male and female are described based on morphological characteristics. Neurosystasis longistylis sp. nov. is similar in appearance to Neurosystasis saltenia (Omad, Mangudo \& Gleiser, 2015), but is readily distinguished based on characters of the head, wing, and male genitalia. In both species, $R_{2+3}$ is attached to vein $R_{4}$, the wing membrane is infuscate with dark spots on vein apices, and lacks sensory organs near the apex of Sc, characters not present in other species of Neurosystasis, and for that reasons we proposed the recovery of Chuspilepia from its synonym and validate it as a subgenus of Neurosystasis to include both continental species. 
Key words: Psychodinae; Maruinini; new species; Puebla; Mexico

RESUMEN. Neurosystasis Satchell es registrado por primera vez en México mediante la descripción de una nueva especie. Los especímenes capturados en un bosque tropical deciduo al sur del estado de Puebla, en el centro de México, fueron examinados y determinados como una nueva especie para la ciencia. El macho y la hembra son descritos con base en las características morfológicas del macho y la hembra. Neurosystasis longistylis sp. nov. es similar a Neurosystasis saltenia (Omad, Mangudo \& Gleiser, 2015), pero se distingue fácilmente con base en las características de la cabeza, ala y genitales del macho. En ambas especies, la vena $R_{2+3}$ está unida a la vena $R_{4}$, la membrana del ala es ahumada con manchas oscuras en los ápices de las venas y carecen de órganos sensoriales cerca del ápice de la vena Sc, características no presentes en otras especies de Neurosystasis, y por esa razón se propone recuperar Chuspilepia de su sinonimia para validarla como un subgénero de Neurosystasis para incluir ambas especies continentales.

Palabras clave: Psychodinae; Maruinini; nueva especie; Puebla; México

\section{INTRODUCTION}

Neurosystasis Satchell, 1955, was originally described as a subgenus of Telmatoscopus Eaton, 1904, but Duckhouse (1974) ranked Neurosystasis to genus status as considered that it is not related with Telmatoscopus, but rather with Alepia Enderlein, 1937. Subsequently, Neurosystasis and Alepia were placed in the tribe Maruinini Enderlein, 1937, based primarily on characters of the wing and male genitalia. Kvifte and Wagner (2017) presented the diagnosis of Neurosystasis, a key for the identification of the previously known species, and the description of two species. This genus currently comprises six species, one recorded in Florida, USA (Satchell, 1955), three from Cuba (Knab, 1914; Kvifte \& Wagner, 2017), one from Jamaica (Wagner \& Hribar, 2010), and another one described in Argentina (Omad et al., 2015), far away from the Caribbean subregion where the bulk of species occur.

In this work, we present the description of a new species of Neurosystasis based on male and female characteristics, corresponding to the first Mexican record of this genus. This Mexican species, in addition to the Argentinean one, indicates an apparently wide distribution in the Neotropics, and probably there are other undescribed species waiting to be recorded.

\section{MATERIALS AND METHODS}

Study area. Collections were made in the locality of Rancho El Salado $\left(18^{\circ} 20^{\prime} 13^{\prime \prime} \mathrm{N}, 98^{\circ} 57^{\prime} 29^{\prime \prime}\right.$ $\mathrm{W}$ ), in the municipality of Jolalpan of the State of Puebla, Mexico. This locality belongs to the physiographic province of Neovolcanic Axis and Sierra Madre del Sur, a component of Cuenca del Balsas of the biogeographic Mexican Transition Zone (Instituto Nacional de Estadística y Geografía, 2009; Morrone, 2005). In this province, the climatic conditions are warm subhumid with summer rainfalls, annual median temperature of $25.4^{\circ} \mathrm{C}$, and annual precipitation mean of $827.1 \mathrm{~mm}$ (TrejoVázquez, 1999). Vegetation consists of tropical deciduous forest with secondary shrub elements. 
Due to seasonality, some arboreal deciduous species in this environment lose their foliage in the dry season for about six months (Rzedowski, 1978).

Specimen collection. Specimens were captured using Miniature CDC-UV light traps (Model 912, John W. Hock Company, Gainesville, FL.) set overnight (19:00 to 7:00 h), dry preserved, and subsequently cleared, dissected, and permanently mounted in Euparal (Bioquip Products, Inc., Rancho Dominguez, CA, USA) on slides, following the procedure outlined by lbáñez-Bernal (2005). Specimens were examined using a Nikon Eclipse 50i phase contrast microscope. Measurements were obtained using an ocular micrometer and are given in millimeters. Drawings were rendered with the aid of a Nikon Y-IDT drawing tube, artwork completed by mixed media drawing technique using Chinese ink and charcoal, and then digitally processed with Corel Photo Paint X3 (Version 13). Specimens are deposited in IEXA: Colección de Insectos del Instituto de Ecología, A.C. (INECOL), Xalapa, Veracruz, Mexico.

Terminology. In general, we follow the morphological terminology of Cumming and Wood (2009). For male terminalia the terminology used was Curler and Moulton (2012), and Kvifte and Wagner (2017), for female postabdomen was Kotrba (2000) with some adjustments presented by Krzemińska and Gorzka (2016) made for the description of Trichocera (Staryia) spp. because their female genitalia are very similar to those of Psychodinae.

Measurements. Head width was measured at the widest part, whereas the length was measured from the vertex to the ventral margin of the clypeus as seen from a frontal perspective. Upper frons length is the distance from the vertex to the upper margin of the eye in frontal view. Wing length is measured from the base of Costa after the basal node to the wing tip. Genital plate width and length was taken at the widest and lengthiest part, respectively. Proportion of the palpus segments are given considering the length of palpus segment I as a unit (1.0).

\section{RESULTS}

Neurosystasis longistylis Durán-Luz, Ibáñez-Bernal \& Omad, sp. nov. http://zoobank.org/urn:Isid:zoobank.org:act:B2EC2306-EDC1-4799-BA0B-E887DC4E7035

(Figs. 1-14)

Diagnosis. Neurosystasis longistylis sp. nov. is distinguished from other Neurosystasis species by the following combination of characters: wing membrane homogeneously smoked with darker infuscations at vein apices; radial fork close to base of $\mathrm{R}_{4}$, stem of CuA runs broadly separated from stem of M (Fig. 4), and hypopod composed of a lateral branch with some tenacula at apex and a truncate mesal branch which is 0.25 the length of the lateral branch (Fig. 9).

Description of male (Figs. 1-9). Head about 1.4 times wider than long; eye bridge with three rows of facets; eyes separated by less than one facet diameter; interocular suture shaped as complete, inverted "V". Frontal patch of alveoli with the ventral margin bilobed, dorsal just reaching the inferior margin of the eye; palpus reaching the level of the median portion of flagellomere 7 , proportion of palp segments: 1.00: 2.70: 2.57: 2.86 (Fig. 1). Labium with inverted "Y" cibarial fork, with five small spiniform setae at each side of " $Y$ " sclerite stem; labellum bulbous with setae on 
apical half and five short spiniform setae on the internal margin (Fig. 2). Antenna incomplete (only the first ten flagellomeres observed); scape 1.5 times the length of pedicel; flagellomeres eccentric, except the first which is symmetrical, each with two rows of small alveoli, each producing a long filamentous sensillum (Fig. 3).

Wing length 2.1 times its width, with the membrane slightly smoked, with dark spots over the apex of all veins and the base of the $R_{5}$; Sc widened at the base, ending at level of $R_{5}$ base; radial sector pectinate; $R_{2+3}$ fork attached to base of $R_{4}$; CuP wider at base (Fig. 4).

Aedeagus asymmetric with the apex like a hook, with an oval tongue-like lobe completely covered with small setae, originated at the union of aedeagal apodeme and aedeagus; aedeagal apodeme two times the length of aedeagus. Gonostyli asymmetric, longer than gonocoxites; left gonostylus curved, with apex acute, right gonostylus nearly straight, with multiple setae and with strong spines inserted at apex (Fig. 5), that if turned, seems widened distally like a golf club. Epandrium asymmetric, $2 X$ wider than long, with two small foramina (Fig. 6, 7), internally with two sclerotized struts which are united at center and fused with the base of subepandrial sclerite with arms ending at base of epandrial lobe (Fig. 8). Epandrial lobe wider at base with a truncated medial lobe that ends in two small lobes with different size, all the medial lobe surface with many fine setae; at middle of the lateral branch, there is a neck and apically it is expanded having more than 10 conelike setae and 2-3 terminal long thin setae (Fig. 9).

Measurements. Head width: $0.587(0.57-0.60) n=7$; head length: $0.411(0.39-0.44) n=7$; length from vertex to dorsal margin of the eye: $0.097(0.09-0.11) n=7$; labrum length: $0.118(0.11-0.13)$ $n=8$; proboscis length: $0.144(0.13-0.15) n=8$; palpus length: $0.610(0.58-0.64) n=8$; wing length: $2.014(1.98-2.13) n=7$; wing width: $0.931(0.90-1.00) n=7$; epandrial lobe length: $0.366(0.35-0.38)$ $\mathrm{n}=8$; aedeagus length: $0.514(0.49-0.53) \mathrm{n}=8$.

Description of female (Figs. 10-14). Head as in male, except by the following characteristics: Proportion of palp segments: 1.0: 2.71: 2.43: 2.71 (Fig. 10). Antennae incomplete (only six flagellomeres were observed in one specimen); ascoids not seen, but the basal two flagellomeres with one large circular alveolus (Fig. 11).

Wing as described for male (Fig. 12).

Genital plate longer than wide; with a slightly concavity on the distal margin, with long setae on the medial region, scattered centrally towards the apex; with a membranous plate on internal surface (Fig. 14). Ventral receptacle with a pair of oval structures with lateral margin rugose and internally with a patch of microsetae, each reinforced by a semicircular sclerotization, with two sclerotized rods that are angularly directed laterally from middle to the posterior portion, and genital chamber with two lateral rods which converge posteriorly, and other pair of diverging rods which ends in a supragenital plate that has a rounded posterior margin and some large sensilla (Fig. 13). Cerci wide with about 0.33 its length, with multiple setae, 1.7 times the length of the genital plate (Fig. 14). 


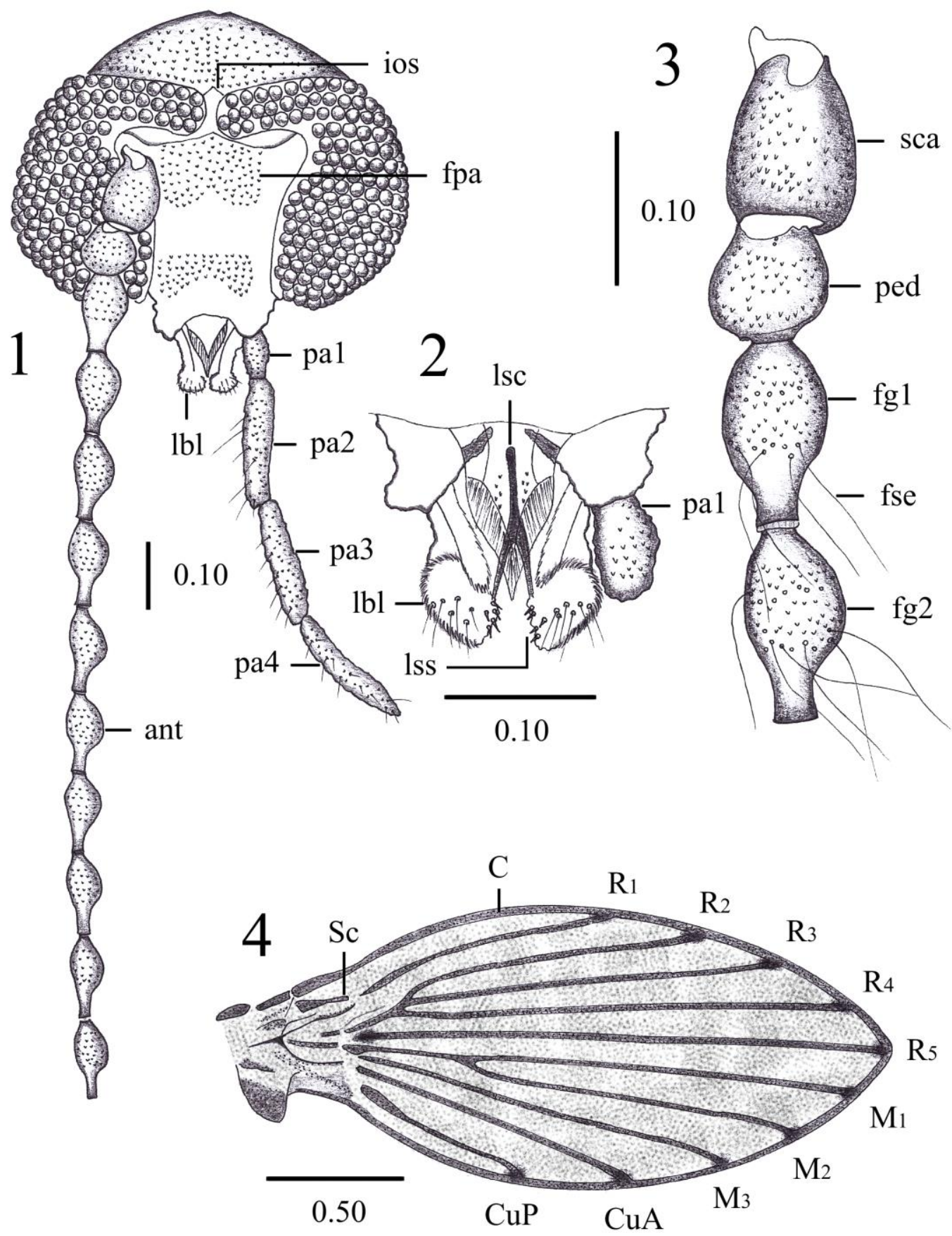

Figures 1-4. Male of Neurosystasis longistylis sp. nov. 1. Head in frontal view, showing incomplete antenna and palpus. 2. Mouthparts and first palpus segment. 3. Scape, pedicel and two first flagellomeres. 4. Wing. Scale in millimeters. Abbreviatures: ant: antenna; fg1: flagellomere one; fg2: flagellomere two; fpa: frontal patch of alveoli; fse: flagellomere filamentous sensilla; ios: interocular suture; Ibl: labellum; Isc: cibarial fork; Iss: labellum spiniform setae; pa1: palpus segment one; pa2: palpus segment two; pa3: palpus segment three; pa4: palpus segment four; ped: pedicel; sca: scape. 

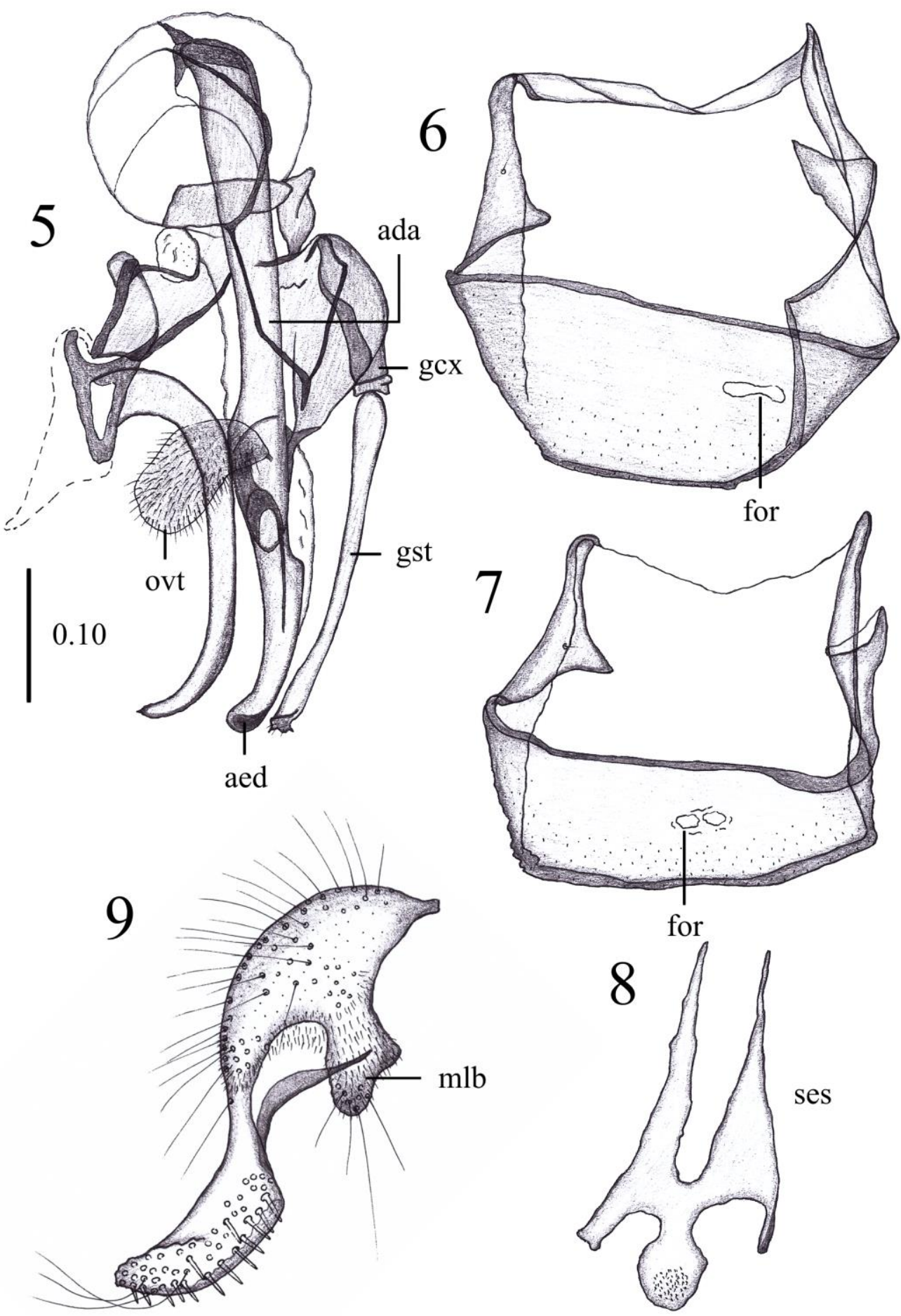

Figures 5-9. Male terminalia of Neurosystasis longistylis sp. nov. 5. Aedeagus and gonopods in dorsoventral view. 6-7. Epandrium. 8. Subepandrial sclerite. 9. Epandrial lobe. Scale in millimeters, all figures at same scale. Abbreviatures: ada: aedeagal apodeme; aed: aedeagus; for: foramina; gcx: gonocoxite; gst: gonostylus; ovt: oval tongue like lobe of aedeagus; ses: subepandrial sclerite; mlb: mesal lobe of hypopodium. 


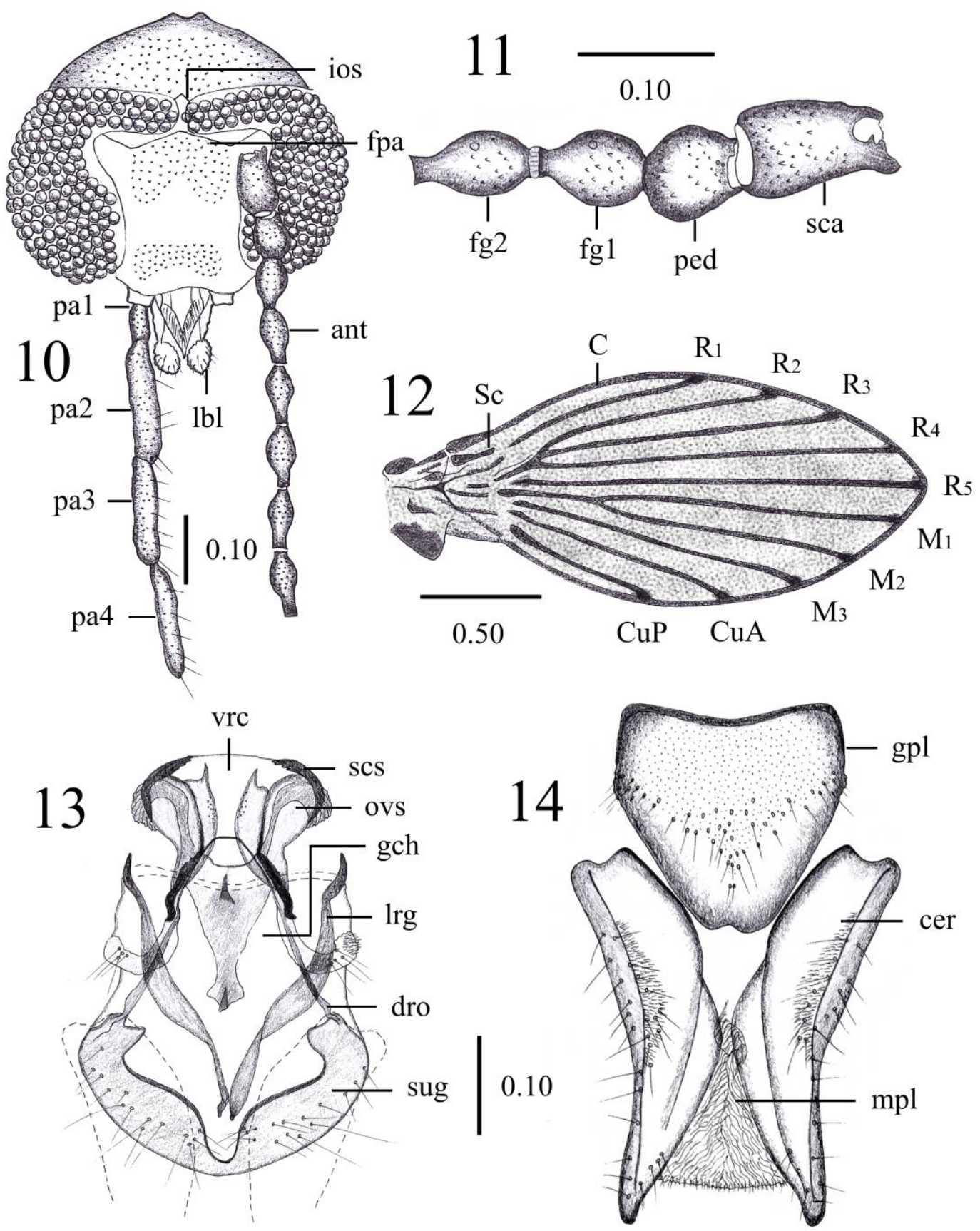

Figures 10-14. Female of Neurosystasis longistylis sp. nov. 10. Head in frontal view with incomplete antenna and palpus. 11. Scape, pedicel and first two flagellomeres. 12. Wing. 13. Genital chamber and ventral receptacle. 14. Genital plate and cerci. Scale in millimeters, figures 13 and 14 at same scale. Abbreviatures: ant: antenna; cer: cercus; dro: divergent rods; fg1: flagellomere one; fg2: flagellomere 2; gch: genital chamber; gpl: genital plate; ios: interocular suture; lbl: labellum; Irg: lateral rods of genital chamber; mpl: membranous plate; ovs: oval structures; pa1: palpus segment one; pa2: palpus segment two; pa3: palpus segment three; pa4: palpus segment four; ped: pedicel; sca: scape; scs: semicircular sclerotization; sug: supragenital plate; vrc: ventral receptacle. 
Measurements $(n=1)$. Head width: 0.55 ; head length: 0.41 ; length from vertex to dorsal margin of the eye: 0.12 ; labrum length: 0.12 ; proboscis length: 0.15 ; palpus length: 0.62 ; wing length: 2.0; wing width: 0.96 ; width of genital plate: 0.24 ; total length of genital plate: 0.23 ; cerci length: 0.38 .

Material examined. Holotype ( $\left.\delta^{\wedge}\right)$. MEXICO: Puebla, Jolalpan, Rancho El Salado $\left(18^{\circ} 20^{\prime} 08.7^{\prime \prime} \mathrm{N}\right.$,

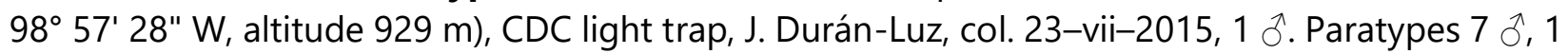

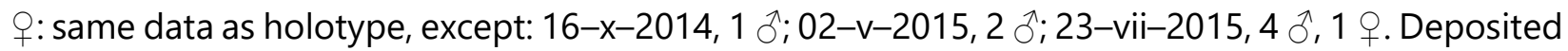
in IEXA: Colección de Insectos del Instituto de Ecología, A.C. (INECOL), Xalapa, Veracruz, Mexico.

Type locality. Mexico, Puebla, Jolalpan, Rancho El Salado.

Etymology. From Latin longus, long; stylis, referring to gonostylus; as the male genitalia have long gonostyli.

\section{DISCUSSION}

This species is considered a member of the genus Neurosystasis because it exhibits asymmetric aedeagus and gonopods in addition to all other characteristics reviewed by Kvifte and Wagner (2017). According to the identification key of Kvifte and Wagner (2017), N. longistylis sp. nov. is easily separated from the other known species because wing membrane is homogeneously infuscate with dark spots at vein apices, the radial fork is attached to the $R_{4}$, the stem of CuA runs broadly separated from stem of $M$, and the epandrial lobe presents a truncate medial lobe 0.25 the length of the lateral branch.

This new species appears similar to Neurosystasis saltenia (Omad, Mangudo \& Gleiser, 2015) because $R_{2+3}$ is attached to vein $R_{4}$, the wing membrane is infuscate with dark spots on vein apices, and lacks sensory organs near the apex of Sc. Also, the male genitalia has the epandrial lobe with a wide base from which a short median branch originates, and no apical retinaculum, but has more than ten cone shaped setae in the apical third and 2-3 long curved setae at apex. Neurosystasis longistylis is differentiated from $N$. saltenia by the former having a head capsule with the interocular suture complete and V-shaped, frontal alveoli patch undivided at midline, and a wing with $\mathrm{CuA}_{2}$ widened at base and lacking white spots between vein apices. The female genitalia of this species are completely different to $N$. saltenia because the last has the genital plate nearly triangular with truncate apex.

Neurosystasis saltenia was described as the type species of Chuspilepia Omad, Mangudo \& Gleiser (=Neurosystasis), who recognized some differences in the wing and male genitalia; it was later determined that some of the characters perceived as unique are also found in other genera of Maruinini. Nonetheless, Neurosystasis saltenia and N. longistylis sp. nov. are the only two species of the genus that do not have a wing with sensory organs (or scent organs) near the apex of Sc, both have dark spots on vein apices, and $\mathrm{R}_{2+3}$ fork attached to base of $\mathrm{R}_{4}$. These differences distinguish the Neotropical continental species from the Circum-Caribbean species. For those reasons, we propose tentatively to recover from its synonym Chuspilepia to be considered a subgenus of Neurosystasis. 


\section{Neurosystasis (Chuspilepia) Omad, Mangudo \& Gleiser, status novo}

http://zoobank.org/urn:Isid:zoobank.org:act:0E1A7F5D-04ED-4E5F-9D9D-2EE7B942D230

Chuspilepia Omad, Mangudo \& Gleiser, 2015: 500 (as genus). Type species: Chuspilepia saltenia Omad, Mangudo \& Gleiser, by original designation. Additional references: Kvifte \& Wagner, 2017: 87 (synonym).

Diagnosis. Wing sensory organs near the apex of Sc absent; vein apices with dark spots; $R_{2+3}$ fork attached to base of $R_{4}$.

Species included. Neurosystasis saltenia Omad, Mangudo \& Gleiser, 2015; Neurosystasis longistylis Durán-Luz, Ibáñez-Bernal \& Omad, sp. nov.

Known distribution. Continental America.

Neurosystasis (Neurosystasis) Satchell, 1955

http://zoobank.org/urn:Isid:zoobank.org:act:E7004536-8697-4A8B-8A48-2D83DEC015B2

Telmatoscopus (Neurosystasis) Satchell, 1955: 86. Type species: Telmatoscopus terminalis Satchell, 1955 , by original designation.

Neurosystasis Satchell: Duckhouse, 1974: 142 (as genus). Additional references: Kvifte \& Wagner, 2017: 82.

Diagnosis. Wing sensory organs near the apex of Sc present; vein apices without dark spots; $R_{2+3}$ fork not attached to base of $R_{4}$.

Species included. Neurosystasis amplipenna (Knab, 1914); Neurosystasis bromeliphila Wagner \& Hribar, 2010; Neurosystasis mira Wagner \& Kvifte, 2017; Neurosystasis starki Wagner, 2017; Neurosystasis terminalis (Satchell, 1955) (Kvifte \& Wagner 2017).

Known distribution. Circum-Caribbean.

ACKNOWLEDGMENTS. JDL was awarded by a scholarship from the Mexican Council of Science and Technology (CONACyT, No. 609598) as part of the work "Estructura del ensamble de Psychodinae (Diptera: Psychodidae) de dos zonas y tres temporadas climáticas contrastantes en la UMA "Rancho El Salado", Jolalpan, Puebla, México". This work was supported by the "Dípteros de importancia médica-veterinaria de la selva baja caducifolia de la mixteca poblana" project under the "Programa para el Desarrollo Profesional para el Tipo Superior (PRODEP) como NPTC con folio BUAP-PTC-438, No. Convenio DSA/103.5/15/7449" program, coordinated by César Antonio Sandoval Ruiz. Also, it was supported by the project INECOL-10816 granted to SIB. We are in debt with Gregory R. Curler and Gunnar Mikalsen Kvifte, for their suggestions to improve this manuscript. 


\section{LITERATURE CITED}

Cumming, J. M., Wood, D. M. (2009) Adult morphology and terminology. Pp. 9-50. In: B. V. Brown, A. Borkent, J. M. Cumming, D. M. Wood, N. E. Woodley, M. A. Zumbado (Eds.). Manual of Central American Diptera. Vol. 1. National Research Council of Canada, Ottawa, Ontario, Canada.

Curler, G. R., Moulton, J. K. (2012) Phylogeny of psychodid subfamilies (Diptera: Psychodidae) inferred from nuclear DNA sequences with a review of morphological evidence for relationship. Systematic Entomology, 37, 603-616. https://doi.org/10.1111/j.1365-3113.2012.00634.x

Duckhouse, D. A. (1974) Redescription of the Neotropical Psychodidae (Diptera, Nematocera) described by Knab, Dyar and Coquillett. Journal of Entomology, 42, 141-152.

Eaton, A. E. (1904) New genera of European Psychodidae. Entomologist's Monthly Magazine, 40, 55-59.

Enderlein, G. (1937) Klassification der Psychodidae (Dipt.). Deutsche Entomologische Zeitschrift, 1936, 81-112.

Ibáñez-Bernal, S. (2005) Phlebotominae (Diptera: Psychodidae) de México. V.-Clave ilustrada para la identificación de los machos de Lutzomyia França. Folia Entomológica Mexicana, 44, 4966.

Instituto Nacional de Estadística y Geografía (2009) Prontuario de información geográfica municipal de los Estados Unidos Mexicanos. Jolalpan, Puebla, México, 9 pp. Available at: http://www3.inegi.org.mx/contenidos/app/mexicocifras/datos_geograficos/21/21087.pdf (accessed in March 2020).

Kotrba, M. (2000) Morphology and terminology of the female postabdomen. Pp. 75-84. In: L. Papp, B. Darvas (Eds.). Contributions to a Manual of Palaearctic Diptera. Vol. 1. Science Herald, Budapest.

Krzemińska, E., Gorzka, D. (2016) Ventral receptacle in the genus Trichocera: A case of parallel evolution between remote lineages of the Diptera (Diptera: Nematocera: Trichoceridae). Zoologischer Anzeiger - A Journal of Comparative Zoology, 263, 6-15. http://dx.doi.org/10.1016/j.jcz.2016.03.014

Kvifte, G. M., Wagner, R. (2017) Review of Neurosystasis Satchell, with two new species from Cuba and a discussion of cerci and surstyli in Psychodinae (Diptera: Psychodidae). Zootaxa, 4306, 81-90. http://dx.doi.org/10.11646/zootaxa.4306.1.4

Knab, F. (1914) New moth flies (Psychodidae) bred from Bromeliaceae and other plants. Proceedings of United States National Museum, 46, 103-106.

https://doi.org/10.5479/si.00963801.2015.103

Morrone, J. J. (2005) Hacia una síntesis biogeográfica de México. Revista Mexicana de Biodiversidad, 76, 207-252.

Omad, G., Mangudo, C., Gleiser, R. M. (2015) New genus of Psychodinae (Diptera, Psychodidae) from Argentina. Iheringia, Série Zoologia, 105, 499-504. https://doi.org/10.1590/1678-476620151054499504

Rzedowski, J. (1978) Vegetación de México. Limusa, México, 431 pp.

Satchell, G. H. (1955) Two new subgenera of Psychodidae (Diptera) from Jamaica, with descriptions of five new species. Annals and Magazine of Natural History, 12, 85-93. 
Trejo-Vázquez, I. (1999) El clima de la selva baja caducifolia en México. Investigaciones Geográficas, 39, 40-52.

Wagner, R., Hribar, L. J. (2010) A new species of moth fly (Diptera, Psychodidae, Psychodinae) collected from Bromeliads in Florida. Zootaxa, 2662, 66-68.

http://dx.doi.org/10.5281/zenodo. 276277 